\title{
PENGANTAR
}

METODOLOGI

PENELITIAN

LINGUISTIK

\section{HARIES PRIBADY}




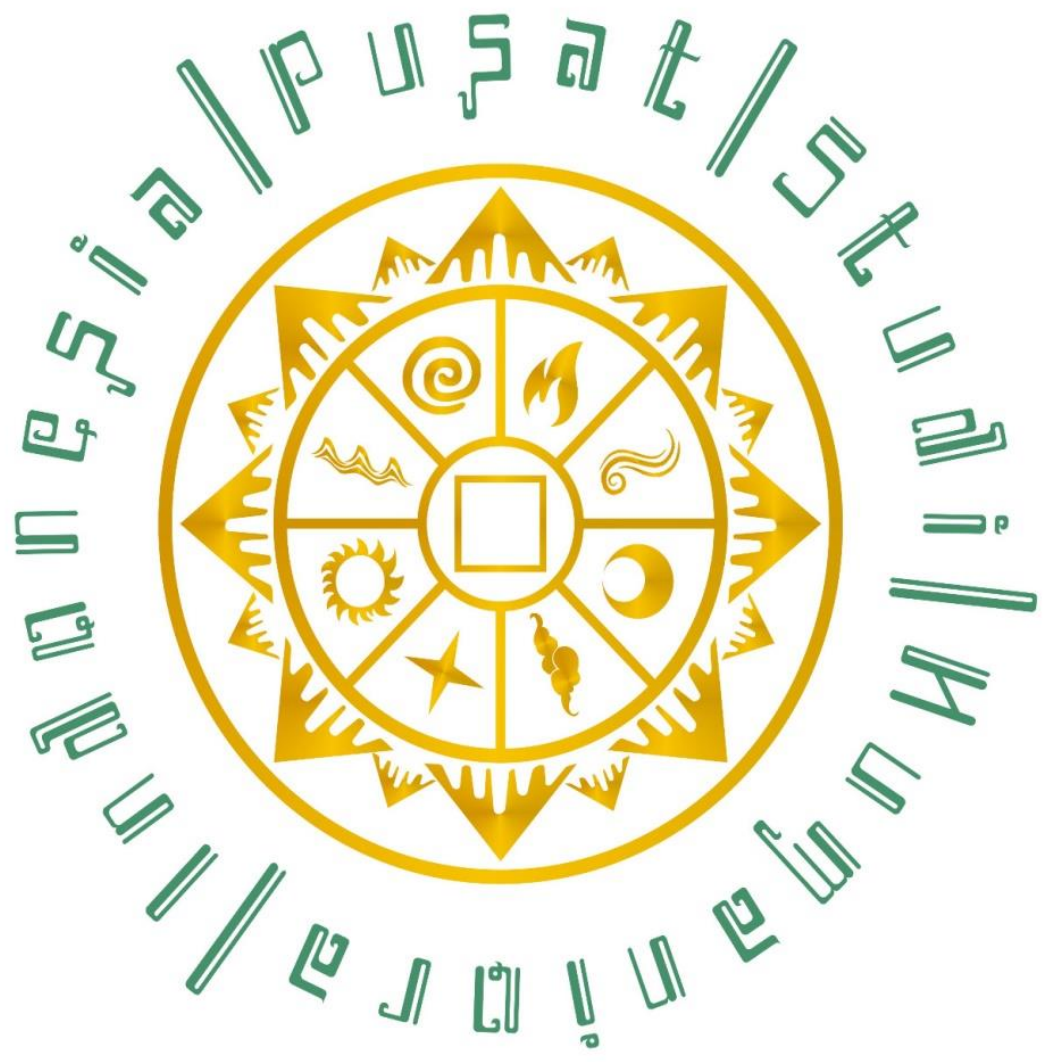

In the Name of Science and Society Dignity 
Ditulis sebagai bentuk pengabdian dan ucapan terima kasih untuk pembimbing skripsi dan tesis, serta dosen di Program Sarjana dan Pascasarjana Pendidikan Bahasa Indonesia FKIP Universitas Tanjungura

1. Dr. Paternus Hanye, M.Pd.

2. Firman Susilo, M.Hum

3. Dr. Sisilya Saman Madeten, M.Pd

4. Dr. Patriantoro. M.Hum

5. Prof. Chairil Effendy, M.S.

6. Dr. Christanto Syam,M.Pd.

7. Dr. Antonius Totok Priyadi ,M.Pd.

8. Dr. Agus Wartiningsih, M.Pd.

9. Dr. Martono, M.Pd.

10. Dr. Sesilia Seli, M.Pd.

11. Dr. Ahadi Sulissusiawan, M.Pd. 


\section{Prakata}

Ungkapan syukur dan puji-pujian disampaikan kepada Tuhan Yang Mahakuasa sebab dengan kehendakNya penulis bisa merampungkan buku saku Pengantar Metodologi Penelitian Linguistik di waktu yang tepat.

Alasan menulis buku ini tidak lain dan tidak bukan adalah untuk membantu peneliti pemula, terutama mahasiswa jurusan Pendidikan Bahasa Indonesia, jurusan Bahasa Indonesia, jurusan bahasa asing, jurusan bahasa daerah, ataupun mahasiswa dari jurusan lain yang menjadikan bahasa sebagai objek penelitiannya.

Beberapa buku yang ditulis oleh peneliti senior memang sudah sangat baik dan cukup untuk dijadikan pedoman serta pegangan, namun berdasarkan pengalaman penulis ketika membimbing penelitian ada beberapa hal yang menjadi catatan. 
Hal pertama adalah kaidah yang dipaparkan di dalam buku metodologi tersebut belum memberikan gambaran praktis terhadap proses sebuah penelitian. Hal kedua, buku metodologi yang ada memaparkan dengan begitu detail tanpa ikut menjelaskan fungsi teknisnya. Dengan demikian, buku ini ditulis sebagai penjembatan bagi mahasiswa atau peneliti pemula untuk memahami sebuah proses penelitian.

Walaupun sifatnya sebagai pengantar, buku ini ditulis dengan asumsi bahwa yang membacanya adalah peneliti yang sama sekali belum pernah melakukan penelitian. Oleh sebab itu, buku ini ditulis dengan gaya bahasa yang semiformal, agar bisa dinikmati dan mudah dipahami oleh mahasiswa dan peneliti pemula.

Benedictus qui venit in nomini Domine, Sambas, Juni 2018

Haries Pribady 


\section{BAB 1}

\section{PENGANTAR}

\section{Skripsi, Apa Sih?}

Dunia mahasiswa adalah dunia yang sangat menakjubkan. Dalam tempo empat tahun bisa jadi banyak sekali perubahan signifikan dalam diri seorang mahasiswa. Pengetahuan bertambah banyak, wawasan dan pengalaman bertambah luas, jaringan tersebar dimana-mana, portofolio organisasi dan riset pun tidak diragukan.

Semua hal itu tampak indah-indah belaka. Hingga tiba suatu saat, di semester

In the Name of Science and Society Dignity 
akhir ketika para mahasiswa dihadapkan dengan tugas akhir yang bernama skripsi. Beberapa mahasiswa, bisa dikatakan sebagian besar, mengalami shock therapy jika berhadapan dengan barang yang satu ini. Bagaimana tidak, dalam pikiran yang sudah terpola sejak zaman lampau menulis skripsi itu sangat susah. Dosen pembimbing kurang kooperatif, literatur terbatas, sumber data yang susah diakses, dan banyak kendala lain yang jika dibahas satu persatu akan menghabiskan berlembar-lembar kertas. Namun inti dari itu semua, mengapa mahasiswa mengalami kesulitan menggarap 
skripsi adalah ketidakmampuan memahami hakikat (esensi) sebuah karya tulis yang bernama skripsi.

Ada beberapa hal yang semestinya menjadi kompetensi lulusan perguruan tinggi. Satu di antaranya adalah kemahiran menghasilkan karya ilmiah/ tulisan ilmiah. Secara sederhana, tulisan ilmiah yang dimaksud berupa hasil kerja ilmiah atau gagasan ilmiah yang dihasilkan secara metodologis dengan runtutan yang sistematis. Mengacu pada hal tersebut, apa sih yang dinamakan skripsi itu? Jawaban singkatnya skripsi adalah laporan hasil penelitian (hasil 
kerja ilmiah). Apa yang seharusnya mahasiswa lakukan untuk pertama kalinya, melakukan penelitian atau menulis laporan hasil peelitian? Jawabanya sudah jelas, mahasiswa harus mampu melakukan penelitian terlebih dulu baru bisa menulis laporannya dalam bentuk skripsi. Tapi sangat disayangkan, beberapa mahasiswa di perguruan tinggi cenderung bersemangat menulis skripsi (bersemangat namun belum mengetahui hakikatnya) tanpa memberikan perhatian lebih pada penelitian itu.

Sebagai langkah awal, perlu dipahami bahwa skripsi adalah produk ilmiah. Produk

In the Name of Science and Society Dignity 
ilmiah ini memiliki lima tahapan. Pertama, melakukan kajian literatur terhadap jurnaljurnal ilmiah. Kedua, menulis proposal (rencana) penelitian. Ketiga, melakukan penelitian. Keempat, menulis laporan hasil penelitian. Kelima, memublikasikan laporan hasil penelitian dalam bentuk jurnal.

Berdasar pengalaman sebagai pembimbing penelitian di kampus, penulis menemukan banyak mahasiswa yang hendak mengajukan judul skripsi tanpa melakukan kajian literatur terlebih dulu. Kajian literatur terhadap jurnal ini pun mesti dilakukan secara intensif, disesuaikan dengan tema

In the Name of Science and Society Dignity 
yang akan diangkat. Pada dasarnya kajian lieteratur ini pun dibagi menjadi tiga. Pertama adalah kajian literatur yang berbentuk similar research by approach yaitu literatur yang pendekatan risetnya akan dijadikan bahan rujukan. Kedua adalah kajian literatur yang berbentuk similar research by object yaitu literatur yang objek risetnya akan dijadikan bahan rujukan. Serta yang ketiga yaitu kajian literatur yang berbentuk similar research by problem yaitu literatur yang masalah risetnya akan dijadikan bahan rujukan. Tindakan yang perlu dilakukan dalam melakukan kajian literatur ini adalah mendata secara detail 
perumusan latar belakang, pemilihan objek, data, metode, dan hasil penelitian. Tujuan melakukan kajian literatur adalah supaya mahasiswa memiliki gambaran yang konkret terhadap judul penelitiannya dan paham aluralur yang harus ditempuh ketika melakukan penelitian dari awal hingga akhir.

Hal selanjutnya yang harus dilakukan adalah menulis proposal penelitian. Bagian ini dirasakan tidak begitu sulit. Dengan banyaknya contoh di perpustakaan dan situs jurnal di internet, mahasiswa akan sangat mudah menulis proposal penelitian. Namun ada satu hal yang perlu mendapat perhatian

In the Name of Science and Society Dignity 
serius, yaitu bagaimana caranya merumuskan latar belakang penelitian dengan tepat. Ketepatan itu dilihat dari sudut pandang apa bahwa yang diteliti merupakan sebuah masalah dan bagaimana dampak yang akan ditimbulkannya jika tidak segera ditangani atau dikaji. Jika proposal sudah selesai ditulis dan periksa vaiditas isinya, penelitian sudah boleh dilakukan. Secara sederhana, melakukan penelitian dalam bagian ini adalah upaya mengumpulkan dan menganalisis data. Data dikumpulkan dengan bantuan instrumen penelitian kemudian dikaji berdasar

In the Name of Science and Society Dignity 
permasalahan dan kajian teori yang telah dikemukakan di dalam proposal.

Setelah melewati ketiga tahap di atas, baru lah mahasiswa menulis laporan hasil penelitian. Hal ini tidak begitu sulit sebab yang dinamakan laporan hasil penelitian hanyalah menambah satu bab pembahasan setelah proposal. Tentu saja haruslah disertai konsultasi secara intensif dengan pembimbing skripsi. Jika itu sudah dilewati, maka proses penulisan skripsi sudah selesai. Di bagian akhir, skripsi yang sudah ditulis itu diringkas kembali agar segera bisa dipublikasikan dalam bentuk jurnal.

In the Name of Science and Society Dignity 
Sebagai simpulan, perlu dipahami oleh para mahasiswa bahwa skripsi adalah produk ilmiah. Adalah suatu kewajiban jika ingin menghasilkan produk ilmiah maka harus mengonsumsi produk ilmiah pula. Artinya adalah kegiatan membaca jurnal, buku teks, dsb. yang merupakan hasil penelitian adalah sesuatu yang tidak boleh dikesampingkan. Untuk menutup tulisan singkat ini, ada sebuah ungkapan yang lazim di masyarakat air yang bening akan keluar dari teko yang telah diisi air bening.

In the Name of Science and Society Dignity 


\section{Similar Research}

\section{SR by APPROACH SR by OBJECT \\ SR by RESEARCH PROBLEM}

Secara sederhana, kajian relevan

(biasa dikenal dengan istilah similar research) adalah bagian dari rangkaian sebuah penelitian.

Kajian relevan diperlukan bagi peneliti, baik peneliti pemula maupun peneliti

In the Name of Science and Society Dignity 
profesional. Bagi peneliti pemula, sebuah proses penelitian adalah suatu hal yang sangat baru dan asing. Dengan melakukan kajian relevan, peneliti pemula akan memeroleh pedoman dan panduan dalam melakukan kegiatannya. Bukan hanya dalam konteks penelitian itu, tetapi juga dalam konteks bagaimana sebuah penelitian dirumuskan dan direncanakan. Adapun bagi peneliti profesional, kajian relevan berguna untuk mencari kaitan ataupun slot-slot kosong yang kemungkinan bisa diisi dan dilengkapi.

In the Name of Science and Society Dignity 
Kajian relevan pada dasarnya terbagi menjadi tiga kelompok. Pertama, kajian relevan berdasarkan objek. Kajian relevan berdasarkan objek merupakan rujukan yang objeknya sama dengan objek yang akan diteliti. Sebagai contoh, di dalam penelitian linguistik Bahasa Melayu Dialek Sambas, aspek-aspeknya dilengkapi satu persatu berdasarkan kapasitas dan minat peneliti. Ada peneliti yang konsen terhadap aspek fonologi, aspek morfologi, aspek semantik, ataupun sintaksisnya. Dari beberapa aspek itu, akan selalu ada aspek yang belum diteliti.

In the Name of Science and Society Dignity 
Tugas peneliti selanjutnya lah yang akan menggenapi aspek tersebut.

Kajian relevan berdasarkan objek memungkinkan penelitian yang komprehenseif terhadap sebuah objek kajian. Dengan konsep ini, sebuah objek akan dibahas dan dianalisis dari pelbagai aspek sehingga memperkaya pandangan ataupun perspektif terhadap objek tersebut.

Kedua, kajian relevan berdasarkan pendekatan. Di dalam sebuah penelitian, pendekatan berfungsi untuk memperjelas analisis. Sebuah objek, dalam satu kali penelitian, biasanya hanya menggunakan

In the Name of Science and Society Dignity 
sebuah pendekatan. Dalam sebuah kasus penelitian pada Bahasa Melayu Dialek Sambas. Objek penelitian bisa dianalisis dari pelbagai pendekatan. Jika peneliti hendak menganalisis Bahasa Melayu Dialek Sambas dengan pendekatan fonologi, maka peneliti mesti mencari penelitian serupa yang membahas fonologi pada bahasa yang lain. Inti dari kajian relevan berbasis pendekatan adalah untuk memudahkan peneliti dalam memahami cara dan langkah kerja penelitian dengan pendekatan tertentu.

Ketiga, kajian relevan berdasarkan masalah penelitian. Masalah dalam sebuah

In the Name of Science and Society Dignity 
penelitian berangkat dari pendekatan yang digunakan. Untuk hal ini, ada hal yang perlu diperhatikan terutama oleh peneliti pemula. Dalam sebuah pendekatan biasanya terdapat banyak aspek yang bisa diangkat menjadi masalah penelitian. Misalnya sebuah penelitian menggunakan pendekatan semantik yang di dalamnya ada banyak aspek. Sedangkan biasanya peneliti pemula hanya menggunakan tiga atau empat aspek. Maka itu, ada penelitian yang objek dan pendekatannya sama, namun masalahnya berbeda. 
Penelitian relevan berbasis masalah memberikan panduan teknis. Dengan mangacu pada penelitian terdahulu yang sama masalahnya, maka peneliti pemula akan mendapatkan informasi yang cukup jelas. 


\section{BAB 2}

KOMPONEN PROPOSAL PENELITIAN

\section{Bagaimana Menulis Latar Belakang Proposal Penelitian?}

Menulis karya ilmiah adalah bagian yang paling menyenangkan dalam perjalanan sebagai seorang mahasiswa. Beberapa mahasiswa sangat bersemangat mengerjakan proyek ini, namun tak sedikit yang enggan bahkan terkesan antipati ketika bersentuhan dengan kegiatan tulis menulis, apalagi tulisan ilmiah yang berbentuk skripsi.

In the Name of Science and Society Dignity 
Karya tulis ilmiah, sesuai denlgan namanya, adalah sebuah karya tulis yang disususn sesuai dengan aturan tertentu. Secara sederhana ianya adalah tulisan yang sistematis dan metodologis. Memiliki alur yang jelas dan dilakukan dengan langkahlangkah yang tepat. Langkah pertama yang harus dilakukan ketika hendak menulis karya ilmiah adalah memerhatikan minat. Minat, walau terdengar simpel, adalah hal yang mendasari dan hal pertama yang menggerakkan mahasiswa untuk menghasilkan sesuatu. Jadi, hal pertama yang mesti diperhatikan adalah ukuran minat

In the Name of Science and Society Dignity 
mahasiswa terhadap sesuatu. Dengan minat yang tinggi, setiap langkah penulisan karya ilmiah akan berjalan dengan lancar. Jika pada saat penulisan ditemukan pelbagai masalah, setidaknya itu adalah konsekuensi yang mesti diterima oleh mahasiswa atas minat yang dipilihnya.

Bagaimana langkah selanjutnya? Langkah kedua yang dilakukan setelah mahasiswa melakukan fit and proper test terhadap minat (study of interest) adalah melakukan kajian literatur. Apakah melakukan kajian literatur adalah hal yang penting? Jawabannya adalah iya. Kajian 26

In the Name of Science and Society Dignity 
literatur adalah sebuah kegiatan membahas, menelaah, atau menganalisis tulisan peneliti terdahulu dengan tujuan memeroleh gambaran yang jelas dan utuh berkenaan dengan penelitian yang akan dilakukan.

Setelah melakukan dua tahap di atas, baru lah mahasiswa bisa memulai menulis latar belakang penelitiannya. Latar belakang adalah bagian pertama dalam organisasi tulisan ilmiah yang mengandung alasanalasan logis dan disertai dengan alasan empiris berkaitan dengan pemilihan objek penelitian. Di dalam latar belakang ini lah penulis mengemukakan pendapatnya secara

In the Name of Science and Society Dignity 
komprehensif dari pelbagai aspek. Latar Belakang adalah bagian dari karya ilmiah yang menjelaskan bahwa sebuah penelitian itu perlu dilakukan disertai alasan-alasan yang logis dan empiris. Alasan yang logis bermaksud bahwa hal yang akan diteliti memiliki kausalitas (hubungan sebab akibat) dengan hal lain, sedangkan alasan yang empris bermaksud bahwa masalah yang akan diteliti telah tampak melalui kegiatan observasi awal. Ada delapan hal yang paling tidak berada di dalam latar belakang.

Pertama, deskripsi objek penelitian (Research Object Description). Objek

In the Name of Science and Society Dignity 
penelitan dapat diterjemahkan sebagai hal apa yang akan diteliti. Linguistik sebagai sebuah kajian ilmu memiliki banyak cabang. Ada yang tergabung ke dalam linguistik mikro (kajian linguistik murni mencakup fonologi, morfologi, semantik, dan sintaksis) dan linguistik makro (kajian interdisiplin linguistik dengan bidang lain, misalnya sosiolinguistik, psikolinguistik, etnolinguistik, neurolinguistik, linguistik forensik, ekolinguistik, dsb.). Di awal latar belakang mahasiswa hendaknya mendeskripsikan 'sesuatu' yang akan mengantarkan pembaca ke cabang linguistik

In the Name of Science and Society Dignity 
tersebut. Lazimnya yang dikemukakan di bagian pertama adalah tinjauan terhadap bahasa sebagai alat komunikasi manusia dan tinjauan terhadap linguistik sebagai alat untuk fenomena berbahasa tersebut.

Kedua, deskripsi objek secara khusus (Specific Description of Research Object). Deskripsi objek secara khusus adalah upaya penulis mengaitkan/ menautkan fenomena berbahasa yang dikemukakan pada bagian pertama dengan bidang linguistik yang akan digunakan sebagai alat analisisnya. Sebagai contoh sederhana, fenomena berbahasa bisa dikaji dari aspek sosiolinguistiknya. Pada

In the Name of Science and Society Dignity 
bagian ini lah penulis menjelaskan secara ringkas 'kemampuan' sosiolinguistik untuk menjelaskan fenomena berbahasa tersebut.

Ketiga, deskripsi masalah yang ditemui (disertai fenomena) (Research Uniqueness or Problem). Bidang linguistik yang diambil sebagai ' alat bedah' dirasa terlalu luas cakupannya. Pada bagian ini lah penulis membatasi cakupan penelitiannya. Pembatasan ini adalah upaya agar penelitian bisa difokuskan ke beberapa hal saja yang dianggap perlu. Cakupan tersebut bisa berupa masalah penelitian yang akan diambil

In the Name of Science and Society Dignity 
maupun ruang lingkup sumber data yang akan digunakan.

Keempat, hal yang akan dilakukan terhadap masalah atau keunikan tersebut (Object Treatment). Sebuah penelitian pada dasarnya bukan sekadar mengumpulkan data kemudian mendeskripsikan atau menginterpretasinya. Data yang sudah diperoleh di lapangan mestilah mendapat perlakuan khusus atau dianalisis dengan dengan pendekatan tertentu. Dengan demikian rumusan masalah yang dikemukakan di bagian ini bisa terjawab sesuai dengan yang peneliti kehendaki.

In the Name of Science and Society Dignity 
Kelima, alasan pemilihan objek penelitian. Alasan pemilihan objek adalah hal penting yang harus dipaparkan di dalam latar belakang. Secara ringkas, alasan pemilihan objek penelitan harus berangkat dari masalah (bisa juga disebut fenomena berbahasa) yang ditemukan di lapangan. Objek dipilih dengan asumsi bahwa hal itu adalah sesuatu yang menarik, penting, dan bermanfaat.

Keenam, alasan pemilihan subjek penelitian. Subjek penelitian (bagi kalangan tertentu disebut sebagai tempat melakukan penelitian, sumber data) adalah lokasi penemuan data. Maksudnya adalah fenomena

In the Name of Science and Society Dignity 
yang berada di dalam subjek ini sifatnya signifikan dibandingkan dengan subjek lain. Signifikansi itu lah satu sebab yang logis dalam penentuan subjek penelitian. Artinya adalah fenomena yang ingin ditelaah terjadi secara intensif di dalam subjek. Semakin intensif kejadian fenomena yang dimaksud, semakin tinggi tingkat signifikansinya. Ada beberapa hal yang bisa dipertimbangkan ketika memilih subjek penelitian. Di antaranya adalah aspek linguistis, aspek historis, aspek demografis, aspek geografis, aspek kultural, aspek sosial, bahkan aspek ekonomi. Tentu saja peneliti harus jeli dalam

In the Name of Science and Society Dignity 
mengemukakan alasan pemilihan subjek berdasarkan aspek tersebut. Upayakan agar aspek tersebut memiliki koherensi dengan masalah yang diambil.

Ketujuh, ringkasan kajian literatur (Research Literature Review Summary). Kajian literatur pada hakikatnya sudah dilakukan sebelum mahasiswa menulis proposal penelitian. Namun tidak ada salahnya mencantumkan beberapa kajian literatur di dalam latar belakang, khususnya dalam bentuk ringkasan. Hal ini bertujuan untuk menegaskan bahwa penelitian yang akan dilakukan merujuk pada sesuatu yang

In the Name of Science and Society Dignity 
akuntabel. Adapun isi dari ringkasan kajian literatur adalah nama, tahun, dan judul. Selanjutnya adalah metode dan teknik penelitian, data, sumber data, dan instrumennya. Terakhir adalah hasil analisis. Perlu juga ditambahkan yaitu kelebihan dan kekurangan penelitian tersebut, serta kaitannya dengan penelitian yang akan mahasiswa lakukan.

Kedelapan, keuntungan jika penelitian itu dilakukan (Research Benefit). Perlu dijelaskan di bagian ini bahwa penelitian mesti memberikan dampak. Keuntungan tidak dilihat dari aspek material-

In the Name of Science and Society Dignity 
ekonomis, namun lebih ke arah nonmaterialfilosofis. Secara detail, keuntungan ini dijabarkan di dalam bagian manfaat penelitian.

Kesembilan, implementasi penelitian di bidang lain. implementasi penelitian di bidang lain sebenarnya bersifat opsional. Bisa dicantumkan atau tidak. Namun, pencantuman implementasi penelitian ini merupakan upaya agar pembaca memahami bahwa penelitian yang akan dilakukan tidak akan berakhir di atas kertas saja. Artinya adalah ada sesuatu yang diharapkan

In the Name of Science and Society Dignity 
bermanfaat dari penelitian yang akan dilakukan.

Beberapa hal yang telah dikemukakan di atas adalah gambaran dasar tentang beberapa hal yang mesti ada dalam setiap latar belakang. Jika mengalami kebingungan dan kebuntuan dalam menuangkan ide, itu artinya adalah mahasiswa yang bersangkutan masih belum banyak membaca. Ada satu hal yang perlu dipahami, bahwa penulis yang baik berasal dari pembaca yang hebat.

In the Name of Science and Society Dignity 
In the Name of Science and Society Dignity 


\section{Memahami Paradigma Masalah}

\section{Penelitian}

Setiap penelitian dilakukan atas sebab

tertentu. Ada penelitian ynag berbasis pada masalah, yakni penelitian yang dilakukan karena peneliti menukan sesuatu yang tidak beres ataupun terjadinya kesenjangan antara harapan dengan kenyataan (antara teori dengan praktik, namun ada juga peneliti yang berbasis pada fenomena-fenomena unik yang ditemukan di dalam penggunaan bahasa.

Penelitian yang berbasis masalah pada umumnya dilakukan untuk menjawab keresahan seorang peneliti. Misalnya sebuah

In the Name of Science and Society Dignity 
penelitian dilakukan untuk mencari tahu sebab-sebab seorang balitia lambat berbicara ataupun penelitian untuk mencari tahu faktorfaktor penyebab kesalahan berbasaha lisantulisan sehingga kesalahan tersebut bias diminimalkan. Penelitian yang berbasis fenomena dilakukan karena peneliti menemukan sebuah keunikan dalam unit-unit lingual yang digunakan di masyarakat. Misalnya adalah penggunaan preposisi maupun konjungsi. Di dalam bahasa Indonesia, sesuai dengan kaidah, konjungsi berfungsi untuk menjembatani konstruksi predikatif yang lazimnya berupa kalimat

In the Name of Science and Society Dignity 
majemuk atau antarkonstruksi predikatif pada kalimat terpisah. Namun di dalam bahasa daerah ditemukan bahwa ada konjungsi yang letaknya justru berada di awal kalimat. Fenomena unik itu lah yang diamati dan dianalisis dengan tujuan agar menemukan pola atau system lignuistik suatu bahasa.

Lantas apa yang dimaksud dengan masalah penelitian? Berdasar pemaparan yang telah dikemukakan di atas dapat disimpulkan bahwa masalah memiliki dua definisi. Pertama, masalah adalah ketimpangan antara penggunaan unit linguistic di kalangan pengguna bahasa

In the Name of Science and Society Dignity 
dengan kaidah yang telah disepakati atau dikodifikasi dalam bentuk aturan-aturan baku. Kedua, masalah adalah bagian dari pendekatan yang dijadikan fokus penelitian terhadap sebuah objek. Focus penelitian ini dapat diterjemahkan sebagai bagian tertentu dari fenomena berbahasa yang menarik untuk dikaji secara serius.

Masalah penelitian di setiap lembaga perguruan tinggi memiliki corak yang berbeda. Corak ini mencakup bagaimana masalah itu dirumuskan serta berapa seharusnya masalah dalam suatu penelitian.

In the Name of Science and Society Dignity 
Pada umumnya masalah penelitian dikemukakan sebagai berikut:

Aspektualitas dalam bahasa-bahasa nusantara muncul melalui keterangan yang sentiasa terikat dengan verba. Keberadaaan aspek mampu menunjukkan unsur waktu dan situasi. Pada dasarnya diperlukan upaya serius untuk bisa membedakan antara aspek dengan kala sebab kedua-duanya menunjukkan unsur waktu. Perbedaan paling mendasar antara keduanya adalah bahwa aspek mengungkapkan waktu secara internal dalam situasi. Ketepatan penggunaan aspektualitas dalam kegiatan berkomunikasi adalah hal yang penting untuk diperhatikan. Aspektualitas memungkinkan seorang pengguna bahasa menggambarkan sebuah situasi dengan tepat sehingga kegiatan komunikasi bisa berjalan secara efektif dan efisien. Setiap bahasa memiliki cara tersendiri untuk mengungkapkan aspektualitas. Hal itu lah yang menjadi fokus penelitian ini. Fokus penelitian diwujudkan dalam tiga masalah.

In the Name of Science and Society Dignity 
a. Bagaimanakah bentuk aspektualitas dalam BMDS?

b. Bagaimanakah makna aspektualitas dalam BMDS?

c. Bagaimanakah fungsi aspektualitas dalam BMDS?

Contoh di atas terdiri atas dua bagian yaitu pengantar dan fokus penelitian. Pengantar penelitian sebaiknya diungkapkan agar peneliti lebih mudah melogikakan atau menjawab sebenarnya ada apa sih? dalam ancangan penelitiannya. Di bagian selanjutnya pengantar tersebut ditulis kembali dalam bentuk yang lebih spesifik dan lazimnya diawali dengan pertanyaan bagaimanakah?.

In the Name of Science and Society Dignity 


\section{Tujuan Penelitian}

Tujuan dirumuskan agar proses penelitian bisa dilaksanakan dengan tepat. Tujuan merupakan luaran yang hendak dicapai.

\section{Manfaat Penelitian}

Manfaat penelitian pada bagian ini dijabarkan secara teknis. Dalam penelitian linguistik, setidaknya penelitian akan bermanfaat bagi lembaga perguruan tinggi, sekolah, lembaga masyarakat, lembaga penelitian, dan sebagainya dengan proporsi manfaat penelitian yang berbeda. Artinya adalah peneliti mesti bisa merumuskan dan

In the Name of Science and Society Dignity 
menentukan, jika penelitian selesai dilaksanakan, maka yang akan merasakan dampaknya adalah pihak-pihak terkait. Beberapa kampus menghendaki mahasiswa untuk menulis manfaat penelitian satu persatu, namun penulis lebih memilih metode penarasian. Selain lebih jelas, penarasian akan membantu pembaca untuk memahami luaran yang diharapkan. Adapun contoh narasi manfaat penelitian adalah sebagai berikut:
"Hasil
penelitian
ini bermanfaat sebagai pelengkap seperangkat teori yang berkaitan dengan aspektualitas. Sebagai bagian dari linguistik, kajian terhadap

In the Name of Science and Society Dignity 
aspektualitas BMDS bermanfaat sebagai alat untuk memeriksa ketepatan penggunaan auxiliaries dalam berkomunikasi.

Aspektualitas sebagai bagian dari kajian semantik fungsional juga terikat dengan aspek morfologi dan sintaksis. Oleh sebab itu hasil dari penelitian ini adalah untuk memudahkan para pengajar bahasa mendeskripsikan dan menyeleksi bentuk aspek yang tepat dalam menghasilkan sebuah teks. Secara spesifik kajian terhadap aspek berperan dalam pembelajaran Bahasa Indonesia yaitu dalam materi kalimat simpleks dan komleks. Dalam Kurikulum 2013, jenis kalimat ini dibahas di kelas $\mathrm{X}$ pada materi Menulis Teks Laporan Hasil Observasi dan di kelas XI pada materi Teks Eksplanasi Kompleks.

Kajian ini menggunakan sumber data berupa cerita rakyat dan kegiatan berkomunikasi yang

In the Name of Science and Society Dignity 
diperoleh dari pelbagai informan. Sebagai bahasa yang berada di antara pengaruh bahasa Indonesia dan asing, penelitian terhadap bahasa-bahasa nusantara (dalam hal ini adalah BMDS) merupakan upaya pemertahanan bahasa dengan pendekatan yang ilmiah."

\section{Ruang Lingkup}

Ruang lingkup merupakan sebuah batasan yang dipilih peneliti untuk penentuan fokus penelitian dan penentuan sumber data yang akan diambil dalam penelitian. Ruang lingkup ini memudahkan peneliti dalam memfokuskan proses penelitiannya.

In the Name of Science and Society Dignity 
Ruang lingkup bisa mencakup waktu penelitian, lokasi penelitian, data dan sumber data penelitian, serta analisis penelitian.

\section{Penjelasan Istilah}

Bagian penjelasan istilah dipaparkan untuk memberikan pemahaman awal berkaitan dengan rencana penelitian yang akan dilakukan. Di beberapa kampus, bagian penjelasan istilah digunakan untuk menjelaskan judul penelitian secara teknis. Peneliti cukup mengambil satu definisi dari pakar untuk tiap istilah, kemudian menyimpulkannya. Simpulan tersebut yang

In the Name of Science and Society Dignity 
menjadi maksud atau makna dari judul yang peneliti ambil.

\section{Kajian Teori}

Kajian teori berupa deskripsi sintesis dan analisis beberapa teori yang pembahasannya mencakup pendekatan dan fokus-fokus penelitian. Kajian teori membantu peneliti dalam memahami data dan analisisnya. Secara teknis, kajian teori membantu peneliti dalam mengenali data, mengolah, hingga memaparkan atau menyajikan data ke dalam sebuah laporan ilmiah.

Hal pertama yang disajikan di dalam kajian teori adalah pendekatan. Dalam

\section{1}

In the Name of Science and Society Dignity 
penulisan proposal penelitian, peneliti mesti menjelaskan pendekatan yang digunakan. Tidak hanya itu, peneliti juga mesti memberikan pertimbangan atas pendekatan yang digunakan. Dengan demikian, ada alasan yang ilmiah terhadap sebuah pendekatan yang digunakan.

Setelah memaparkan pendekatan yang digunakan, langkah selanjutnya adalah memaparkan teori-teori yang berkenaan dengan masalah penelitian. Jika masalah yang diambil ada tiga, maka teori yang berkaitan dengan masalah tersebut mesti dikemukakan secara komprehensif.

\section{2}

In the Name of Science and Society Dignity 
Beberapa peneliti pemula mengalami kesulitan di bagian kajian teori. Namun pada hakikatnya bagian ini adalah bagian yang paling mudah. Jika kesulitan yang dialami adalah ketika menulis, maka yang bisa dilakukan adalah sebagai berikut:

$>$ Kumpulkan lima hingga enam teori yang berkaitan dengan masalah penelitian.

$>$ Paparkan tiap teori ke dalam tulisan.

$>$ Ambil sebuah simpulan dari teoriteori tersebut.

53

In the Name of Science and Society Dignity 
Metodologi merupakan landasan pemikiran dalam memilih dan melaksanakan sebuah metode. Berkaitan dengan metodologi, Kothari (2004:8) berpendapat bahwa "The scope of research methodology is wider than that of research methods. Thus, when we talk of research methodology we not only talk of the research methods but also consider the logic behind the methods we use in the context of our research study." 'Ruang lingkup metodologi penelitian lebih luas daripada metode penelitian. Metodologi tidak sekadar membahas metode, ianya juga

In the Name of Science and Society Dignity 
membahas logika yang melandasi pelaksanaan penelitian.' Pendapat ini diperkuat oleh Kazdin ( dalam Kaufman, 2005:22) yang menyatakan bahwa “... methodology refers to the principles,procedures, and practices that govern research." 'Metodologi merujuk pada prinsip, prosedur, dan pelatihan yang harus dikuasi oleh peneliti.' Metodologi secara sederhana diterjemahkan sebagai sebuah kajian tentang metode.

Pendapat tersebut didukung oleh Kaufman (2005:22) yang menyatakan bahwa "Methodology should be thought of as

In the Name of Science and Society Dignity 
encompassing the entire process of conducting research (i.e., planning and conducting the research study, drawing conclusions, and disseminating the findings)." 'Metodologi merupakan sebuah cara pikir dalam melaksanakan seluruh rangkaian penelitian ( termasuk merencanakan dan melaksanakan penelitian, menghasilkan simpulan, serta memublikasikan hasilnya).' Selanjutnya Djajasudarma (2006:1) mengungkapkan bahwa metodologi di dalam penelitian linguistik harus dipertimbangkan dari dua segi. Pertama dari segi penelitian itu sendiri

In the Name of Science and Society Dignity 
yang mencakup pengumpulan data beserta cara dan teknik serta prosedur yang ditempuh. Kedua dari segi metode kajian (analisis) yang melibatkan pendekatan (teori) sebagai alat analisis data penelitian. Berdasar beberapa pendapat di atas dapat disimpulkan bahwa metodologi adalah landasan berpikir ataupun seperangkat cara yang digunakan dalam melaksanakan sebuah penelitian.

Berikut adalah beberapa hal yang mesti tercantum di dalam bagian Metodologi Penelitian sebuah proposal.

In the Name of Science and Society Dignity 
Langkah konkret yang diambil untuk pelaksanaan penelitian adalah menentukan metodenya. Kothari (2004:7) menyebutkan bahwa "Research methods may be understood as all those methods/techniques that are used for conduction of research. Research methods or techniques, thus, refer to the methods the researchers." "Metode penelitian bisa dipahami sebagai keseluruhan metode atau teknik yang digunakan untuk melaksanakan penelitian.' Jadi dapat disimpulkan bahwa metode adalah langkah-

In the Name of Science and Society Dignity 
langkah yang dilakukan dalam melakukan sebuah penelitian.

Untuk membantu peneliti pemula merumuskan metode, ada beberapa pertanyaan panduan yang jawabannya adalah hal-hal yang seharusnya terdapat dalam subbab metode.

1. Apa yang dimaksud metode penelitian?

2. Apa metode penelitian yang Anda gunakan?

3. Mengapa memilih metode tersebut? 


\section{Bentuk Penelitian}

Penelitian lignuistik lazimnya berda di bawah payung paradigma penelitian kualitatif. Berg (2001:3) menjelaskan bahwa "Qualitative research thus refers to the meanings,concepts, definitions, characteristics, metaphors, symbols, and descriptions ofthings." 'Penelitian kualitatif merupakan sebuah pendekatan yang mendeskripsikan makna, konsep, definisi, metafora, dan benda.' Kothari (2004:3) menyatakan bahwa "Qualitative research, on the other hand, is concerned with qualitative phenomenon, i.e., phenomena relating to or 
involving quality or kind." 'Penelitian kualitatif berfokus pada fenomena-fenomena kualitatif, misalnya fenomena yang menghubungkan atau untuk meningkatkan kualitas atau sifat.' Pendapat tersebut didukung oleh Kaufman (2005:17) menjelaskan bahwa "Qualitative research involves studies that do not attempt to quantifytheir results through statistical summary or analysis. Qualitative studiestypically involve interviews and observations without formal measurement." 'Penelitian dengan bentuk kualitatif tidak menggunakan statistik untuk menemukan

61

In the Name of Science and Society Dignity 
hasilnya. Bentuk kualitatif cenderung menggunakan wawancara dan observasi tanpa alat ukut yang formal.'

Pendapat ini dipertegas oleh Moleong (2009:6) yang menyatakan bahwa penelitian kualitatif adalah penelitian yang bermaksud untuk memahami fenomena tentang apa yang dialami oleh subjek penelitian, misalnya perilaku, persepsi, motivasi, dan lain-lain secara holistik, dan dengan cara deskripsi dalam bentuk kata-kata dan bahasa, pada suatu konteks khusus yang alamiah dan dengan memanfaatkan berbagai metode ilmiah. Oleh karena itu, dalam penelitian 
kualitatif, data yang dianalisis dan diuraikan dalam bentuk kata-kata atau kalimat berdasarkan data di lapangan.

Bentuk kualitatif dipilih karena alasan tertentu. Berg (2001:10) menjelaskan bahwa "Although various technologies may be used by different researchers, it turns out that everyone is doing science, provided that science is defined as a specific and systematic way of discovering and understanding how social realities arise, operate, and impact on individuals and organizations of individuals." 'Hal ini menunjukkan meskipun pelbagai teknologi digunakan oleh peneliti 
yang berbeda, sains tetap lah didefinisikan sebagai cara yang spesifik dan sistematis untuk menemukan dan memahami realitas sosial serta dampaknya terhadap individu dan kelompoknya.'

Untuk membantu peneliti pemula merumuskan bentuk penelitian, ada beberapa pertanyaan panduan yang jawabannya adalah hal-hal yang seharusnya terdapat dalam subbab bentuk penelitian.

1. Apa yang dimaksud dengan bentuk penelitian?

2. Apa bentuk penelitian yang Anda gunakan? Jelaskan!

In the Name of Science and Society Dignity 
3. Mengapa memilih bentuk penelitian tersebut?

\section{Data dan Sumber Data}

Data merupakan sesuatu yang dibutuhkan peneliti untuk menjawab rumusan masalah. Kaufman (2005:208) menyatakan bahwa "As mentioned earlier, research data can be seen as the fruit of researchers' labor. If a study has been conducted in a scientifically rigorous manner, the data will hold the clues necessary to answer the researchers' questions." "Seperti yang telah dikemukakan di awal, data merupakan hasil kerja peneliti. Data yang diperoleh mampu menjawab 
rumusan masalah jika penelitian dilakukan dengan asas saintifik. Data merupakan bahan yang dianalisis sehingga bisa menemukan sistem atau pola-pola lingual yang diinginkan.

Sumber data merupakan objek yang dipilih untuk memeroleh data. Kothari (2004:95) menjelaskan bahwa "The task of data collection begins after a research problem has been defined and research design/plan chalked out. While deciding about the method of data collection to be used for the study, the researcher should keep in mind two types of data viz., primary and 
secondary". 'Kegiatan mengumpulkan data dimulai ketika masalah penelitian diidentifikasi dan rencana penelitiannya sudah matang. Ketika akan menentukan metode pengumpulan data, peneliti harus memerhatikan jenis data yang diambil dan sumbernya, jenis data primer atau sekunder.' Sumber data ini secara sederhana diartikan sebagai asal ditemukannya data.

Untuk membantu peneliti pemula merumuskan data dan sumber data, ada beberapa pertanyaan panduan yang jawabannya adalah hal-hal yang seharusnya terdapat dalam subbab data dan sumber data.

In the Name of Science and Society Dignity 
1. Apa itu data?

2. Apa data yang digunakan dalam penelitian Anda?

3. Apa itu sumber data?

4. Apa sumber data dalam penelitian Anda?

\section{Metode Pengumpul Data}

Metode pengumpulan data merupakan langkah yang digunakan untuk memeroleh data. Metode yang digunakan dalam penelitian ini adalah metode simak. Setiap metode yang dipilih dalam penelitian diwujudkan dalam sebuah teknik atau langlah kerja yang lebih spesifik. Instrumen

In the Name of Science and Society Dignity 
pengumpul data adalah ungkapan lingual yang digunakan untuk menjaring data. Sedangkan alat pengumpul data adalah media yang digunakan untuk menjaring data tersebut.

Untuk membantu peneliti pemula merumuskan teknik dan alat pengumpul data, ada beberapa pertanyaan panduan yang jawabannya adalah hal-hal yang seharusnya terdapat dalam subbab teknik dan alat pengumpul data.

1. Apa itu teknik pengumpul data?

2. Apa teknik pengumpul data yang Anda gunakan?

69

In the Name of Science and Society Dignity 
3. Apa itu alat pengumpul data?

4. Apa alat pengumpul data yang Anda

gunakan?

5. Mengapa memilih alat itu?

\section{Teknik Analisis Data}

Analisis merupakan langkah yang dilakukan jika data sudah terkumpul melalui teknik-teknik yang telah dilakukan. Analisis data adalah suatu proses mengatur urutan data, mengorganisasikannya ke dalam suatu pola, kategori, dan satu uraian dasar (Patton dalam Muhammad, 2011:221).

Ada tiga hal yang mesti dipaparkan dalam bagian ini.

In the Name of Science and Society Dignity 


\section{Tahap Penyediaan Data}

Tahap ini bukan berarti data masih di lapangan. Pada tahap ini data sudah dikumpulkan dan siap untuk diolah. Namun mesti melewati tahap-tahapan berikut:

\section{Transkripsi Data}

Transkripsi data adalah kegiatan mengubah data lisan hasil rekaman menjadi data tulisan. Transkripsi adalah hal pertama yang dilakukan dalam tahap persiapan data. Hal ini dilakukan agar analisis bisa dikerjakan dengan lebih mudah dan terarah.

In the Name of Science and Society Dignity 
Identifikasi Data

Langkah selanjutnya adalah melakukan identifikasi data. Identifikasi adalah kegiatan menentukan bagian tertentu dalam sumber data. Di dalam kegiatan identfikasi peneliti membedekan antara data dengan bukan data. Setelah ditentukan, data yang dimaksud dimasukkan ke dalam kartu data dan diberi nomor dengan sistem tertentu.

Klasifikasi Data

Langkah terakhir di tahap persiapan data adalah melakukan klasifikasi. Klasifikasi atau pengelompokan adalah kegiatan menggolongkan data sesuai dengan masalah

In the Name of Science and Society Dignity 
penelitian yang telah ditentukan. Kegiatan klasifikasi dilakukan agar analisis bisa dilaksanakan secara teratur. Klasifikasi dilakukan pada kartu data yang kedua.

2. Tahap Analisis Data

Ada dua metode yang lazim digunakan dalam analisis penelitian linguistik, yakni metode agih dan metode padan. Kedua metode ini memiliki karakteristik tersendiri. Tetapi ketika masuk ke dalam proses analisis yang sebenarnya, peneliti harus memilih satu di antara dua metode tersebut. Satu hal yang sangat penting

In the Name of Science and Society Dignity 
adalah peneliti harus bisa menjelaskan alasan pemilihan metode yang dipilih.

Metode analisis adalah sistem kerja, adapun secara praktis metode tersebut diperinci dengan menggunakan teknik-teknik. Dalam satu penelitian, sangat memungkinkan bagi peneliti untuk menggunakan lebih dari satu teknik. Adapun contohnya adalah sebagai berikut:

"Berdasarkan masalah yang telah dirumuskan, metode yang digunakan dalam penelitian ini adalah metode agih (distribusional) yaitu metode yang menggunakan unit lingual dari bahasa yang dianalisis. Sudaryanto (2015:16) menyatakan bahwa alat penentu dalam metode agih selalu berupa bagian atau unsur dari bahasa objek

In the Name of Science and Society Dignity 
sasaran penelitian itu sendiri, seperti kata, fungsi sintaksis, klausa, silaba kata, atau lainnya. Selanjutnya Sumarlam (2004:68) menyatakan bahwa metode agih diterapkan untuk mengkaji hubungan antarunsur dalam satuan yang lebih besar, misalnya hubungan antara morfem terikat yang berupa afiks dengan morfem bebas yang di dekatnya. Metode ini juga mengkaji hubungan antarkata dalam frasa, hubungan antarklausa dalam kalimat, dalam rangka mencari pola-pola aspektualitas. Metode ini kemudian diterapkan ke dalam pelbagai teknik analisis sesuai dengan permasalahannya.

1. Analisis bentuk aspek dengan memerhatikan bentuk gramatikalnya. Analisis bentuk dilakukan dengan memerhatikan satuan linguistik yang menjadi aspek. Kemudian satuan linguistik diklasifikasi ke dalam beberapa jenis, yaitu bentuk dasar, bentuk berimbuhan, atau bentuk reduplikasi. Analisis ini menggunakan teknik perluasan (ekspansi). Teknik

In the Name of Science and Society Dignity 
perluasan adalah sebuah analisis yang mengubah satuan lingual menjadi lebih kompleks. Penerapan teknik ini dapat diperhatikan pada contoh data berikut:

a) Slamet nulis layang 'Slamet menulis surat'

b) Slamet lagi nulis layang 'Slamet sedang menulis surat'

2. Analisis makna aspek dengan menentukan makna yang muncul dengan kehadiran aspektualitas tersebut. Makna berkaitan dengan waktu dan situasi yang mampu ditunjukkan oleh aspektualitas. Analisis ini menggunakan teknik penyulihan (substitusi). Teknik penyulihan atau teknik substitusi digunakan untuk mengetahui kadar kesamaan kelas atau kategori unsur terganti. Contoh teknik ini adalah sebagai berikut:

a) Ayam udah makan cacing tadek malam.

'Ayam sudah makan cacing tadi malam.'

In the Name of Science and Society Dignity 
b) *Ayam nak makan cacing tadek malam.

'Ayam akan makan cacing tadi malam.'

Penggantian aspektualitas $u d a h$ dengan nak pada kalimat (a) dan (b) memiliki bentuk distribusi yang sama. Namun penggunaan nak pada kalimat (b) tidak gramatikal sebab ada pertentangan antara penggunaan nak dengan $u d a h$. Analisis makna aspek dilakukan untuk menentukan jenis makna yang muncul (lugas atau tidak lugas). Sedangkan analisis fungsi dilakukan untuk menentukan peran aspek secara sintaksis, apakah sebagai inti atau pun bukan inti secara sintaksis.

3. Analisis fungsi dilakukan untuk melihat peran aspektualitas sebagai penyerta verba. Fungsinya adalah sebagai auxiliaries (pelengkap) atau deictic (penunjuk). Analisis ini menggunakan teknik pelesapan (elipsis). Sumarlam (2004:69) menjelaskan bahwa teknik pelesapan atau elipsis adalah teknik

In the Name of Science and Society Dignity 
analisis data yang dilakukan dengan cara menghilangkan satuan lingual untuk mengetahui sejauh mana peranan satuan-satuan lingual. Penerapan teknik ini dapat diperhatikan pada contoh data berikut:
a) Tono ngantemi Toni
'Tono memukuli Toni'
b) Tono ngantem Toni
'Tono memukul Toni'

Teknik ini digunakan untuk mengetahui perubahan situasi kalimat atau makna aspektualitas yang disebabkan oleh pelesapan salah satu unsurnya. Dalam penelitian ini unsur yang dilesapkan adalah unsur yang menjadi titik fokus analisis."

In the Name of Science and Society Dignity 
3. Tahap Penyajian Hasil Analisis

Pemaparan atau penyajian data merupakan langkah terakhir dalam sebuah penelitian. Data disajikan dalam bentuk deskriptif, yaitu disampaikan dengan jelas dan detail. Untuk memudahkan pemahaman, data bisa juga disajikan dalam bentuk tabel. Data yang disajikan (dilaporkan) dalam bentuk tesis harus disusun secara konsisten dan sistematis. Oleh sebab itu, diperlukan suatu metode penyajian hasil analisis.

In the Name of Science and Society Dignity 


\section{LAMPIRAN}

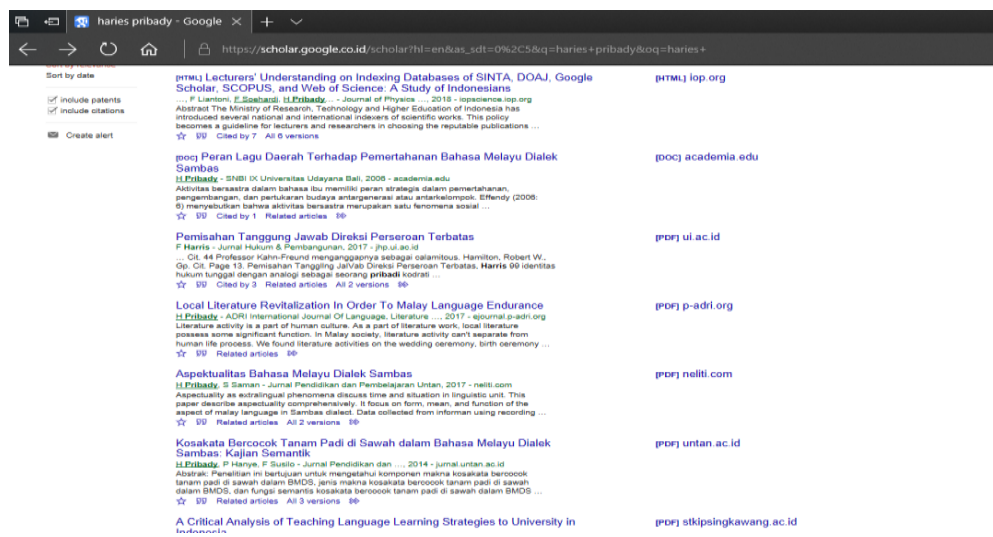

(Tampilan pencarian jurnal di Google Scholar)

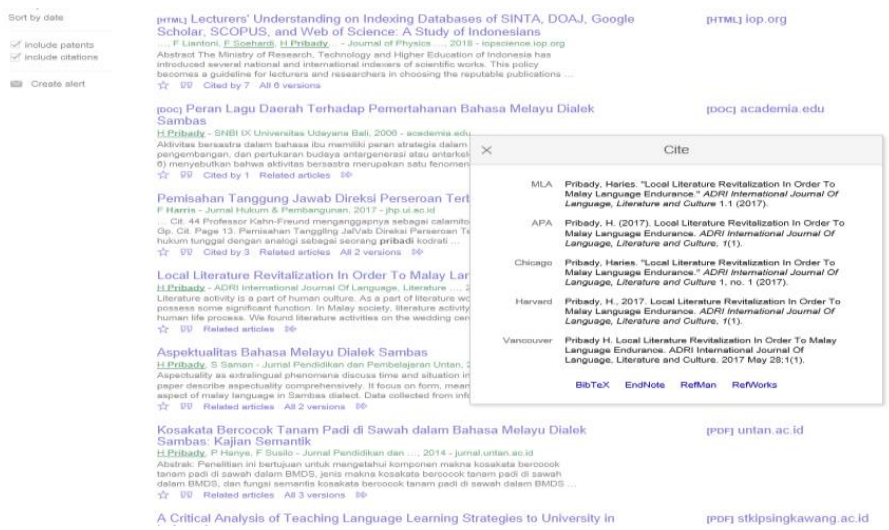

(Klik simbol (") akan muncul tulisan cite/ kutip. Maka akan muncul gambar di atas. Silakan klik jenis pengutipan yang diinginkan, lalu tempel ke 


\section{daftar pustaka. Sebagian besar kampus di Indonesia menggunakan gaya pengutipan Harvard. )}

\section{PERNYATAAN KEASLIAN TULISAN}

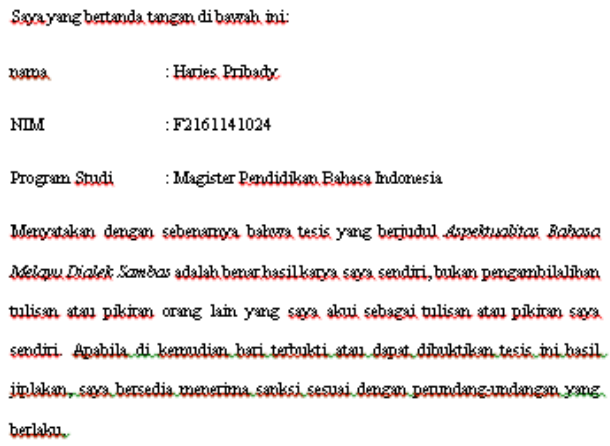

(Contoh surat pernyataan keaslian tulisan) 


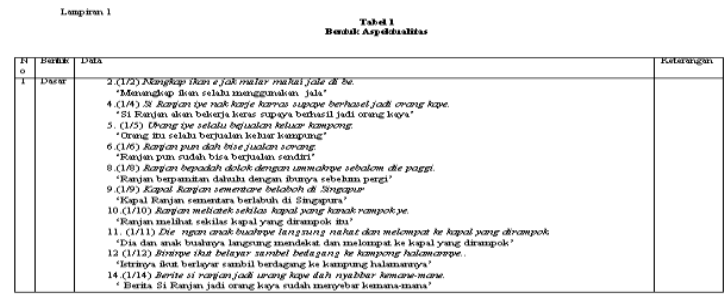

(Kegiatan Mengidentifikasi Data)

Lampiran 2

Tabe 2

Malna Aspetiualitis Bahasa Melyyu Dialek Sambs

\begin{tabular}{|c|c|c|c|}
\hline No & $\begin{array}{c}\text { Malna } \\
\text { Appestualitas }\end{array}$ & $\begin{array}{c}\text { Penarash } \\
\text { Fomal } \\
\text { Aspektualitas }\end{array}$ & Centoh Data \\
\hline 1 & Thkostif & $\begin{array}{l}\text { Nak } \\
\text { Maile }\end{array}$ & 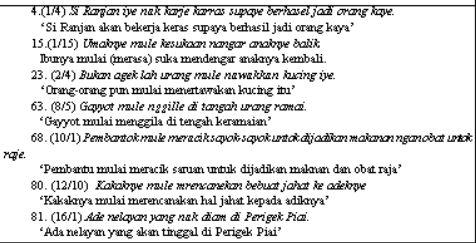 \\
\hline 2 & Progesif & Agek & 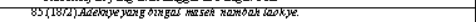 \\
\hline
\end{tabular}

(Kegiatan Mengklasifikasi Data)

82

In the Name of Science and Society Dignity 


\section{Biografi Pengarang}

\section{HARIES PRIBADY}

BEKUT, 7 APRIL 1993

hariespribady@yahoo.com

\section{Education Background:}

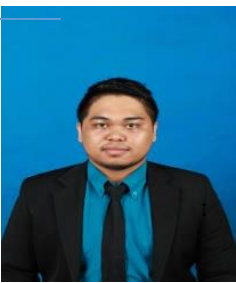

1. TK AISN Bekut, graduated on 1998

2. SDN 23 Bekut, graduated on 2004

3. SMPN 1 Tebas, graduated on 2007

4. SMAN 1 Tebas, graduated on 2010

5. Bachelor of Indonesian Language Teaching Department (S-1) Universitas Tanjungpura, graduated on July 2014

6. Master of Indonesian Language Teaching Department (S-

2) Universitas Tanjungpura, graduated on January 2017

\section{Achievement:}

1. Sampoerna Foundation Scholarsip awardee on 20072010

2. West Kalimantan Language Ambassador on 2011

3. Lippo Group Scholarship awardee on 2012-2014

Activity:

1. Delegasi Kalimantan Barat pada Jambore Nasional Bahasa dan Sastra tahun 2011

2. Delegasi Universitas Tanjungpura pada Indonesia Leadership Camp Universitas Indonesia 2012

3. Program Director of Borneo Student Summit, Malaysia tahun 2012

4. Delegasi Indonesia pada Trans Java Bali Biodiesel Expedition tahun 2012 
5. Peserta International Nusantara Manuscript Symposium tahun 2013

6. Delegasi Indonesia pada International Youth and Cultural Conference tahun 2013

7. Delegasi Universitas Tanjungpura dalam Petrogas Days UI 2013

8. Penyaji makalah pada Seminar Internasional Riksa Bahasa Universitas Pendidikan Indonesia tahun 2015

9. Penyaji makalah pada Seminar Nasional Bahasa Ibu Universitas Udayana Denpasar pada 2016

10. Penyaji makalah pada Seminar Pendidikan Nasional, Singkawang 2016

11. Penyaji makalah pada ADRI International Seminar, Pontianak 2016

12. Program Director of $6^{\text {th }}$ Dies Natalis of STKIP Singkawang

13. Program Director of Singkawang Youth Forum 2018

\section{Scientific Publication}

\section{ASPEKTUALITAS BAHASA MELAYU DIALEK}

\section{SAMBAS}

H Pribady, S Saman, Jurnal Pendidikan dan Pembelajaran 6 (6) tahun 2017

2. Local Literature Revitalization In Order To Malay

Language Endurance

Haries Pribady

ADRI International Journal Of Language, Literature and Culture 1 (1) tahun 2017

3. Pemarkah Frasa Aspektualitas Bahasa Melayu Dialek

$\underline{\text { Sambas }}$

Haries Pribady

JP-BSI (Jurnal Pendidikan Bahasa dan Sastra Indonesia)

1 (2), 76-82 tahun 2016

4. KOSAKATA BERCOCOK TANAM PADI DI SAWAH

DALAM BAHASA MELAYU DIALEK SAMBAS: 
KAJIAN SEMANTIK tahun 2014Haries Pribady, P Hanye, F Susilo

Jurnal Pendidikan dan Pembelajaran 3 (9) tahun 2014 


\section{BIBLIOGRAPHY}

Ahmar, A. S., Kurniasih, N., Irawan, D. E., Sutiksno, D. U., Napitupulu, D., Hafid, H., ... \& Iskandar, A. (2018, January). Lecturers' Understanding on Indexing Databases of SINTA, DOAJ, Google Scholar, SCOPUS, and Web of Science: A Study of Indonesians. In Journal of Physics: Conference Series (Vol. 954, No. 1, p. 012026). IOP Publishing.

Berg, Bruce L.2001. Qualitative Research Method for the Social Sciences. Amerika Serikat: Allyn and Bacon Pearson Education Company.

Chaer, Abdul. 2015. Sintaksis Bahasa Indonesia. Jakarta: PT Rineka Cipta.

Comrie, Bernard. 1998. Aspect. Amerika Serikat: Cambridge University Press.

Djajasudarma, Fatimah. 2009. Metode

Linguistik: Ancangan Metode

Penelitian dan Kajian. Bandung:

Refika Aditama. 
Kaufman, Alan S dan Nadeen L. Kaufman. 2005. Essentials of Research Design and Methodology. Amerika Serikat: John Wiley and Sons Inc.

Kothari, C.R. 2004. Research Methodology:

Methods and Techniques. New

Delhi:New Age International Publishers

Kridalaksana, Harimurti. 2008. Kamus

Linguistik. Jakarta: Gramdia Pustaka Utama.

Mahsun, M.S.2007. Metode Penelitian

Bahasa: Tahapan Strategi, Metode, dan Tekniknya. Jakarta: PT Raja Grafindo Persada.

Moleong, Lexy. 2009. Metode Penelitian

Kualitatif. Bandung: Remaja Rosdakarya.

Muhammad. 2011. Metode Penelitian Bahasa. Jogjakarta: Ar Ruzz Media.

In the Name of Science and Society Dignity 
Nawawi, Hadari. 2015. Metode Penelitian

Bidang Sosial. Yogyakarta: UGM Press.

Pribady, H. (2006). Peran Lagu Daerah Terhadap

Pemertahanan Bahasa Melayu Dialek Sambas.

SNBI IX Universitas Udayana Bali.

Pribady, H., Hanye, P. and Susilo, F., 2014. Kosakata Bercocok Tanam Padi di Sawah dalam Bahasa Melayu Dialek Sambas: Kajian Semantik.

Jurnal Pendidikan dan Pembelajaran, 3(9).

Pribady, H., 2017. Local Literature Revitalization In Order To Malay Language Endurance. ADRI International Journal of Language, Literature and Culture, $1(1)$.

Pribady, H. and Saman, S., 2017. Aspektualitas Bahasa Melayu Dialek Sambas. Jurnal Pendidikan dan Pembelajaran Untan, 6(6).

Putrayasa, Ida Bagus. 2010. Analisis Kalimat. Bandung: Refika Aditama.

Rasdana, Oki. 2013. "Aspektualitas Bahasa Banjar Hulu”. Skripsi. Universitas Pekanbaru Riau. 
Richards, Jack.C dan Richard Shmidt. 2010.

Longman Dictionary of Language

Teaching and Applied Linguistics.

Great Britain: Pearson Education

Limited.

Scollon, Ron dan Suzanne Wong Scollon.

1995.Intercultural Communication: A

Discourse Approach. Massachusetts:

Blackwell Publishers.

Sudaryanto. 2015. Metode dan Aneka Teknik Analisis Bahasa. Yogyakarta: Sanata Dharma University Press.

Sumarlam. 2004. Aspektualitas Bahasa Jawa: Kajian Morfologi dan Sintaksis. Surakarta: Pustaka Cakra.

Tadjuddin, Mohammad. 2005. Aspektualitas dalam Kajian Linguistik. Bandung: PT Alumni.

Verhaar, J.W.M. 2012. Asas-asas Linguistik Umum. Yogyakarta: GMU Press.

In the Name of Science and Society Dignity 


\section{Yule, George. 2015. Kajian Bahasa. Yogyakarta: Pustaka Pelajar.}

